\title{
Student Engagement: Concepts, Development and Application in Malaysian Universities
}

\section{Maria Chong Abdullah*}

Department Foundation of Education, Faculty of Educational Studies, Universiti Putra Malaysia, 43400 Serdang, Selangor, Malaysia

mariac@upm.edu.my

Teoh, H.C.

Department Foundation of Education, Faculty of Educational Studies, Universiti Putra Malaysia, 43400 Serdang, Selangor, Malaysia

\section{Samsilah Roslan}

Department Foundation of Education, Faculty of Educational Studies, Universiti Putra Malaysia, 43400 Serdang, Selangor, Malaysia

\section{Jegak Uli}

Faculty of Defence and Studies Management, National Defence University of Malaysia, Kem Sungai Besi, 57000 Kuala Lumpur, Malaysia

\section{Doi:10.5901/jesr.2015.v5n2p275}

\section{Abstract}

The purpose of this article is to analyse, evaluate and synthesise the concept and development of student engagement in higher education institutions so that the possibility of application in Malaysian universities can be realised. The main discussion of this article is organised into four sections. The first section focuses on the definition of engagement and on why it is important for higher education institutions. In the second, the article describes the antecedent of the concept and its evolution over the last thirty years. The third section analyses critically the function of student engagement as a proxy, means or end in research. Finally, the article highlights the necessity, limitations, and implications of adapting student engagement to the Malaysian context. Through the overview, it is proven that student engagement is a concept well developed in theory and practice. Various studies have proven the effectiveness of student engagement in serving institutional and individual development. With this understanding of the concept of student engagement, perhaps it will widen and deepen the perception of administrators, lecturers, and the general public towards the development of higher education. Subsequently, is may increase undergraduates' level of commitment and meet the challenge of society.

Keywords: Student engagement; concepts; evolution; Malaysian universities.

\section{Introduction}

The concept of student engagement has growing importance in serving two higher education objectives: institutional and individual development. At the institutional level, there are certain positive policies and practices associated with student engagement which directly increase institutional productivity (Kuh \& Hu, 2001). Student engagement helps administrators to identify activities that engaged students and areas of improvement in higher educational institutions (Pike \& Kuh, 2005a). With proper resource allocation to boost student engagement, learning productivity can be increased with fewer costs (Kuh, Pace \& Vesper, 1997).

On the other hand, students, if fully engaged with those facilities and opportunities provided by higher institutions, will improve their learning, grades and personal development (Carini, Kuh \& Klein, 2006; Kuh, Chen \& Nelson Laird, 2007). The concept of student engagement has also been treated as a solution to the lower graduation rate of low income and first-generation college students (Engle \& Tinto, 2008). Some studies examine the relationship between student engagement and persistence (Pascarella \& Terenzini, 2005; Tinto, 2000). Others conclude that engaging in 
various educational activities will affect the quality of after-college life in a positive way (Kuh, 2009; Pascarella \& Terenzini, 2005).

This research is therefore aimed to achieve the following specific objectives:

(1) To analyse the concept of student engagement in higher education institution.

(2) To synthesise the development of student engagement for the past thirty years.

(3) To analyse the function of student engagement in higher education institution.

(4) To evaluate the application of the concept of student engagement in Malaysian context.

\section{Methodology}

This research paper is a preliminary study on the concept and development of student engagement in higher learning institution. The expected outcome of this research paper is to produce a framework for the application of student engagement in Malaysian context. Researchers intend to provide a critical review of the concept of student engagement, overview the development of student engagement, explain the function of student engagement in higher learning institutions, and proposed the possibility of the application of student engagement in Malaysian higher learning institutions.

In order to achieve the objectives stated in this study, the following four steps have been applied to review the relevant article journals and reading materials.

Figure 1: Four Steps Procedure of Literature Review

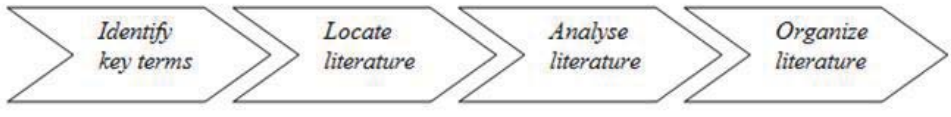

Source: Creswell (2008).

Researchers started the search by identifying the key term "student engagement". After analysed the articles identified in the searching process, researchers further expanded the searching process with other relevant terms such as, "quality of effort", "student involvement", "social and academic integration" and "good quality in undergraduate practice" to capture as many related concepts as possible.

With the above key terms identified, the ERIC (Educational Resources Information Center) database available in university library was visited to explore the article journals and other reading materials (such as academic magazine, monograph, educational reports and etc).

A diagram or literature map was used to provide a visual picture of the literature found (Creswell, 2008). This literature map allowed researchers to display the idea of the study in the organized and manageable form so as the discussion of the literature can be drafted. The literature map was produced as following after the articles being analysed.

Figure 2: Literature Map for the Concept of Student Engagement

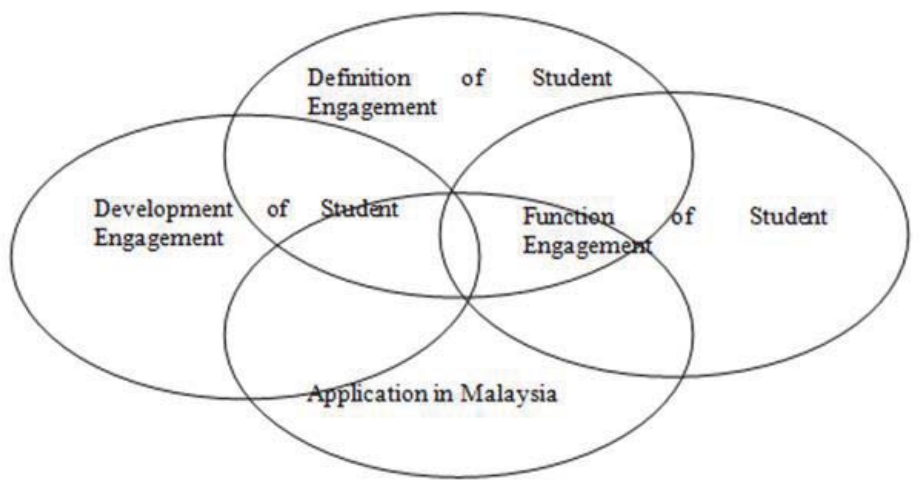




\section{What is Engagement?}

The notion of engagement has been discussed in the literature for more than seventy years (Kuh, 2009). It appeared in different terminology but referred to the same concept i.e. that "students learn from what they do in college" (Pike \& Kuh, $2005 a$, p186). C. Robert Pace was the one scholar who promoted the idea of "quality of student effort" in the 1980s (Astin \& Schroeder, 2003) and laid down foundation for the later research works. Thus, based on Kuh's (2009) classification of the evolution of terminology for engagement, it can be divided into the following subheadings. This section will describe each definition, concept, and construct to investigate the ways in which they vary and overlap.

\subsection{Quality of effort}

Pace (1984) believed that education is both a process and a product. There are certainly some processes which are better than others and will contribute to a good product. Pace (1982) also argued that students are not buying a product from higher education institutions, because students are actually the product of these institutions at a later point in time. Therefore, those students who can invest more time and effort into their learning process will gain more, or will, in other words become better product at the end of their studies. This concept underlies the idea of student engagement and lays down the principle of measuring the process instead of product in higher education. In line with this, Pace measures the quality of effort using two dimensions, frequency and quality. Elsewhere, however, he (1998) has admitted that quality of effort is operationally defined by the activities outlined in the College Student Experiences Questionnaire (CSEQ), but is without scientific, psychological-educational, or dictionary definitions. He tried to describe quality of effort as a voluntary behaviour that reflects initiative, motivation and persistence in students' personal investment in their own higher education studies.

\subsection{Theory of student involvement}

Astin (1999, p. 518) defined student involvement as "the amount of physical and psychological energy that the student devotes to the academic experience". Students learn more if they participate more in both the academic and social experiences afforded by college life. Student involvement can be regarded as a measurable or observable construct of motivation where the emphasis is placed more on the behavioural states than on cognitive or affective domains. In order to elaborate the theory of student involvement, Astin has set up five basic postulates which argue that "the more physical and psychological energy that the student invests in his/her academic experience, the more engaged he/she is to his/her academic life" (Fauziah Md. Jaafar, Rosna Awang Hashim \& Tengku Faekah Tengku Ariffin, 2012, p. 17).

\subsection{Social and academic integration}

Tinto discussed the idea of student engagement from entire a different angle. His concern was more with the dropout from higher education, persistence and student attrition (Tinto, 1987). He studied (1975) the process of dropout and produced a conceptual schema for dropout from college. He argues that a successful interaction between individual, the academic and social system of higher education institutions will prevent students making dropout decisions during their college life. Referring to this conceptual schema, academic integration is associated with grade performance and intellectual development, while social integration is formed by peer-group and faculty interactions. Hypothetically, low commitment to either academic or social integration will cause dropout in student collegiate experiences.

\subsection{Good practice in undergraduate education}

In 1987, after synthesising teaching and learning research in undergraduate education, Chickering and Gamson developed a well-known set of engagement indicators. They name the indicators Seven Principles for Good Practice in Undergraduate Education and briefly described them as (1) encourages contacts between students and faculty; (2) develops reciprocity and cooperation among students; (3) uses active learning techniques; (4) gives prompt feedback; (5) emphasises time on tasks; (6) communicates high expectations; and (7) respects diverse talents and ways of learning (1987).

These seven principles provided six powerful forces: activity, cooperation, diversity, expectation, interaction, and responsibility in education. Their effects on engagement will multiply if all of them are present in an educational setting. 
These seven principles are an all-round consideration pertaining teaching, learning and administration, and will benefit faculty members, students, administrators, and policy makers in colleges and universities (ibid).

\subsection{College outcomes}

Unlike Tinto, who is concerned with the dropout or departure rate of college and universities students, Pascarella and Terenzini (2005) analyse the impacts of higher education on the college outcomes of undergraduates. The college outcomes are grouped into eight different headings: verbal development, competency, cognition, psychosocial domain, values, educational attainment, career, and quality of life. Pascarella and Terenzini have not presented any new ideas, principles or theories to achieve these outcomes. However, they stated that "one of the most inescapable and unequivocal conclusions we can make is that the impact of college is largely determined by the individual's quality of effort and level of involvement in both academic and non-academic activities." (1991, p. 610). After thoroughly reviewing the quantitative and qualitative studies, Pascarella and Terenzini have provided evidence to support the concept of engagement and its contributions to college outcomes.

\subsection{Student engagement}

Today, student engagement is a term that represents the quality of effort and level of involvement in undergraduate studies (Kuh, 2009). Carini, Kuh and Klein (2006, p. 2) have stated that the premise of student engagement is perhaps self-evident the more students study or practice a subject, the more they tend to learn about it. One measuring student engagement is that it indirectly measures the cognitive and personal development of student college experiences (Pascarella, Seifert \& Blaich, 2010). However, as Pace (1998) noted in relation to the concept of quality of effort, student engagement is similar in that it has not been defined academically. Thus, the five benchmarks in National Survey of Student Engagement (NSSE) - level of academic challenge, active and collaborative, student-faculty interaction, enriching educational experience, and supportive campus environment - can be used as an operational definition of student engagement.

\subsection{Summary}

There are strengths and limitations of the description or definition of the meaning, concepts and constructs of student engagement that appear in various terminologies. First, the core idea of student engagement for all these terms can be condensed into two components, time and effort. Pace (1982, p. 4) has given us the clear statement that "all learning and development requires an investment of time and effort by the student". Second, the exploration on the research question "effort at what" has brought out a variety of constructs regarding student engagement. The "seven principles" and "five benchmarks" share some similarities as both of them try to resolve this question. Third, the in-depth discussion of different dimensions enriches the understanding about the functional roles of student engagement, such as physical and psychological, social and academic, institutional and individual, withdrawal and persistence, and contribution to various college outcomes. However, the variety of terminologies and absence of a consensus on a definition confuses readers and obstructs its development. Bowen (2005) stated that there is no explicit consensus on what we meant by engagement and why it is important. In addition, the concept of student engagement is not considered a main construct, not does it explicitly describe the conceptual characteristics in some of the reports (Coates, 2006). It may be because the explanation does not accurately reflect writers' ideas.

\section{Development of Student Engagement}

The concept of student engagement is not new to education but continued to play a more essential role in higher education institutions, especially in the USA (Coates, 2006). This enthusiasm clearly is reflected in the increase of institutional participation in administering the NSSE on their campuses. However, the NSSE is not the first instrument designed to assess student engagement in colleges and universities. In fact, the majority items of used in the original NSSE were similar to or the same as the questions stated in CSEQ (Kuh, 2009). Kuh has also noted that "NSSE'S conceptual roots go back several decades in the form of efforts to document the conditions that promote student learning" (Kuh, 2001, p. 12). Some of the pioneers referred to in these remarks include Alexander Astin, Arthur Chickering and Zelda Gamson. It is useful to look back at the three most influential antecedents of the concept of student 
engagement: Pace's (1982) idea of "quality of effort", Chieckering and Gamson (1987) with the "seven principles for good practice in undergraduate education", and Astin's (1985) "theory of involvement" are sufficient in revealing much of the contemporary understanding of student engagement (Coates, 2006).

There are three lines of argument which prompted Pace to spend thirty years in dealing with the idea of "quality of effort". This first is that Pace believes there are processes in education which are inherently better than others, regardless of their result. The second argument is that all personal and educational development requires an investment of time and effort. There are certain types of educational activities which require more effort than others. Another line of argument is that the failure of an undergraduate in higher education cannot be blamed purely on colleges or universities; students should be made accountable for the amount, scope, and quality of effort they invest in their own learning and development (1984, p. 6).

Based on the idea of "quality of effort", Pace (1990) developed the College Student Experiences Questionnaire and obtained responses from seventy-four colleges, with thousands of students answering the questionnaire between 1983 and 1986. The CSEQ dealt directly with the experiences of undergraduates and concluded with many valuable findings against criticisms of high education institutions that time. Astin gave credit to Pace's studies and reports because he helped to promote the idea of student engagement and underpin the development of the concept of student engagement (Astin \& Schroeder, 2003). Hitherto, the instrument used in measuring the construct of engagement, either CSEQ or NSSE, got the idea from Pace.

Seven Principles for Good Practice in Undergraduate Education is a set of engagement indicators according to $\mathrm{Hu}$ and Kuh (2002). Unlike "quality of effort", which measures what students are actually doing, the "seven principles" provide guidelines and conditions that can be practiced by administrators, staff and policy makers (Coaste, 2006). Kuh and $\mathrm{Hu}$ (2001) believed that the use of these principles by instructors will bring about changes in students' behaviour, for example increased faculty-student interaction, active learning activities and cooperation among students. Pascarella and Terenzini (2005) affirmed that the principles enhance learning, while others suggested that they also produce promising outcomes (Kuh, Pace \& Vesper, 1997).

Coates (2006) had noted that contemporary student engagement research owed much to Astin's work on the "theory of involvement". In 1984, as a major contributor to a study group, Astin produced a landmark national report, Involvement in Learning: Realizing the Potential of American Higher Education (National Institute of Education, 1984), which underscored the importance of student involvement in achievement.

In the development of student engagement, Pace was the pioneer in underpinning its measurement concept with the CSEQ. Yet Astin is the one who unified the theoretical and conceptual idea of student engagement. His five postulate theory of involvement established the foundations for the development of student engagement. According to Astin (1999), the idea of involvement can be regarded as emphasising the behavioural aspects of motivation, but not the cognitive or affective aspects. In other words, Astin (1985) argued that education is a service rather than an industrial production process. Students who go to colleges and universities are already a "full functioning organism"; education just enhances and "adds value" to their situation. Therefore, unlike product quality which is highly dependent on the environment and factory processes, student development in education is highly dependent on the behaviour of individual.

To encapsulate this section, one brief explanation that can be drawn is that the concept of student engagement is rooted in the theory of involvement, which can be identified and put into practice with CSEQ. The application in higher education is rationalised with the "seven principles" and made relevant to instructors, students and administrators. All these elements have been absorbed into NSSE and are currently playing a very essential role in helping colleges and universities to enhance their quality.

\section{Engagement: As a Means or an End}

In this section, the issue of whether " engagement [is] a means to an end, a proxy or an end to itself" (Shulman, 2002, p. 38) will be explored in detail, in order to establish its position for engagement in educational research. Perhaps the variable of engagement can serve in either position of educational research. The purpose of this discussion is simply to clarify its role in various situations.

In the early days of studies conducted by Pace (1982, 1984 and 1990), he put a lot of effort to compare the contribution of quality of effort with other variables such as demographic, college status and environmental factors to personal development and academic achievement. According Pascarella and Terenzini's (2005) analysis, student engagement plays a formative role in affecting college outcomes. It was further contended that student engagement had significant impacts on liberal arts outcomes, especially for first year undergraduates (Pascarella, Seifert \& Blaich, 2010). 
In such circumstances, student engagement is treated as a mediating or explanatory variable used to predict other educational outcomes (Astin, 1999; Coates, 2006). For instance, engagement has been used to predict college dropout or retention (Tinto, 2000). Engaging in various educational productive activities is also positively linked with life quality after college (Kuh, 2009; Pascarella \& Terenzini, 2005), and can enhance general academic abilities, critical thinking skills, grades, and persistence rates (Pike \& Kuh, 2005b). Undoubtedly, the ultimate aim of Pace's studies was to explore the possibility of quality of effort to function as an end itself, or at least as the proxy to understanding and explaining student learning and development (Pace, 1999). However, it seems unlikely, at least at that time, that student engagement could overshadow other educational outcomes, especially grades.

A number of studies have been conducted since the concept of engagement was first introduced. Most of this research treated student engagement as a proxy to universities' other desired outcomes (Kuh, Nelson Laird \& Umbach, 2004). The main reasons are possibly that direct outcomes cannot be measured or the right time for measuring did not present itself (Shulman, 2002). Many colleges practice and educational interventions have used student engagement as a proxy to other desire outcomes, for instance student engagement as a proxy to research experiences ( $\mathrm{Hu}$, Kuh \& Gayles, 2007), a proxy to deep learning (Coates, 2006; Kuh, Chen \& Nelson Laird, 2007), or a proxy to inquiry-oriented activities (Hu, Kuh \& Li, 2008).

However, as Pace (1982, p. 4) noted in his earlier research, "education is both a process and product". This statement was supported by Astin (1985), whoe further explained that education is not about producing products, but adding value to students. The idea of process indicators was best described in the Seven Principles for Good Practice in Undergraduate Education (Ckickering \& Gamson, 1987). Therefore, a process-oriented approach is better than a outcomes-oriented approach to analysing the aim of education (Coates, 2006). As Shulman (2002, p. 40) wrote, "Engagement in this sense is not just a proxy for learning but a fundamental purpose of education."

There are several reasons to support the development of process indicators such as student engagement being used instead of product indicators in higher education. Firstly, student engagement as a process indicator provides a valuable and holistic perspective on the student experience in higher education. Student experiences in colleges or universities are not covered by classroom and academic activities but also by out-of-class, social and non-academic activities. Traditional product indicators have failed to cover all of these perspectives. Secondly, according to Shulman, "being engaged" is intrinsically important in itself. Engagement represents individuals who are "living the life of the university student" (Coates, 2006, p. 32). Students expose themselves to people, various activities and take advantage of different facilities that are important agents of personal and professional growth. Thus this experience, though a process of collegiate life, provides quality of involvement and serves as a worthwhile end. Lastly, process indicators can overcome many limitations of product indicators. Product indicators involve difficulties in determining which outcomes to consider, difficulties of measurement, are limited in capacity and locally based, and are difficult to interpret. Conversely, process data is easier to assess, proximal, tangible, ready to use, easier to interpret, and easier to apply in improving the quality of education (Coates, 2006; Kuh, Pace \& Vesper, 1997). In Pace's words, "what account [matters] most is not who you are or where you are but what you do" (1998, p. 28). As such, there is a trend where student engagement is moving from the role of mediator or proxy, toward becoming the ultimate end of education.

\section{Student Engagement in the Malaysian Context}

This last section will consider the applicability of student engagement in the Malaysian context. This section will highlight the necessity, limitations, and implications of adapting student engagement to Malaysian higher education.

As a global player, the Malaysian government is sensitive to the global economic climate. Malaysia needs human capital with ability to think; committed leaders with vision intellect and confidence; and risk takers (National Higher Education Strategic Plan, 2007).

In this regard, one of the strategies adopted is to enhance the quality of tertiary education. Thus, the National Higher Education Strategic Plan: Laying the Foundation Beyond 2020 was launched in 2007 with the aim of underlying the action plan for tertiary education development in Malaysia. For this purpose, Malaysian Qualifications Framework (MQF, Malaysian Qualifications Agency, 2007) has been implemented "as a basis for quality assurance of higher education and as the reference point for the criteria and standards for national qualifications". MQF places the emphasis on the learning outcomes of these higher education institutions. The outcomes of the learning framework include the problem solving ability; autonomy in decision making and ethics; the attitude towards lifelong learning; professionalism; social responsibility; accountability; and willingness to contribute to the community, nation and global as a whole. These are very much similar to the college outcomes discussed by Pascarella and Terenzini (2005). However, caution needs to 
be taken with what has been proposed by Astin (1999, pp. 519-520),

On the input end of this black box (student) are the various policies and programs of a college or university; on the output end are various types of achievement measures such as the GPA or scores on standardized tests. It seemed that something was missing: some mediating mechanism that would explain how these educational programs and policies are translated into student achievement and development.

Nobody denies the effectiveness and theoretical foundation of the policies, implementations and practices of Malaysian universities. Nevertheless, this article is concerned more with the mechanism of monitoring and measuring the process from input to output. Besides, the outcome-oriented approach is no longer considered effective in comparison to process indicators. Student engagement can work better in bridging the gap between input and output.

In addition, the efforts of policy makers or government action plans in tertiary education will end without results if the learners themselves are not involved and engaged in the process. In his studies, Pace makes precisely this point. Are the learners now more conscious about the effects of learning and about future challenges? Are they ready to develop a more holistic learning approach to future tasks and responsibilities? The dynamics interrelatedness between learning environment and student engagement will determine the success or failure of the "education revolution" and "economic transformation".

Furthermore, recent investigations showed that higher education institutions are facing more signs of disengagement or lack of commitment (McInnis, 2001). In other words, there are more students graduating with higher grades after doing less (Kuh, 1998). Based on constructs of student engagement such as student-faculty interaction and active learning, the same scenario of disengagement can be observed in Malaysian context. Thang $(2005,2009)$, and Thang and Azarina Alias (2007) have found that the majority of students in public and private Malaysian universities were teacher-centred and lacked personal autonomy. This finding is in line with the research results which show that Asian students are prone to low levels of in-class participation (Dasari, 2009; Tani, 2005). Siti Maziha and Nik Suryani (2011) further define negatively passive participation as quietness in class, disregard for class activities, apathy towards lessons, and shyness.

Undeniably, the phenomenon of disengagement exists in Malaysian higher institutions. Poor understanding of this concept makes universities reluctant to take effective solutions, from curriculum design to student support services. This ignorance may further result in responsive actions failing to rectify the mistakes but deteriorating the situation. Finally, if tertiary education fails to lead the learning experience and curriculum management advice to engage students with intellectual and personal development, we may lose in the competition of nurturing talent and in the global economy (McInnis, 2001). Inasmuch as the function of student engagement is vital for institutional and personal development, a better description and understanding of student engagement is necessary for administrators, lecturers, students and policy makers.

The application of the student engagement concept be subject to certain limitations. For instance, despite the spread of NSSE in USA and Canada, the discussion of this concept has only begun in other parts of the world, such as Australia (Griffin, Coates, McInnis \& James, 2003). Besides, cross sectional studies such as NSSE could have produced highly misleading conclusions if not done longitudinally (Astin, 2003). The issues may also differ, as in USA phenomena such as the place of residence, students' employment, and withdrawal attracted much concern from the authorities; whereas in Malaysian context, perhaps academic involvement, parental education, first- and second-generation freshmen are more relevant. Therefore, the initiative to develope and validate the local context measurement model is appropriate and timely (Fauziah Md. Jaafar et al., 2012).

\section{Conclusion}

Higher education institutions play a pivotal role in cultivating researchers and educating skilled workers for the nation. Colleges and universities are responsible for providing various resources, facilities, opportunities, programmes, and courses in order to stimulate student learning and development (Pace, 1982). However, learning is not a passive process in which learners do not gain much by just sitting and listening (Chickering \& Gamson, 1987). The amount of time and effort devoted to productive educational activities will determine the achievement of undergraduates. Student engagement is a concept that has been developed theoretically and practically. Various studies have proven the effectiveness of student engagement in serving institutional and individual development. The hope is that greater understanding of the concept of student engagement will widen and deepen the perception of administrators and lecturers towards the development of higher education. Subsequently, they may increase the level of undergraduate's 
commitment and meet the challenges of society.

\section{References}

Astin, A. W. (1985). Achieving Educational Excellence: A Critical Analysis of Priorities and Practices in Higher Education. San Francisco, CA: Jossey Bass.

Astin, A.W. (1999, originally published July 1984). Student Involvement: A developmental theory for higher education. Journal of College Student Personnel, 25, 518-529.

Astin, A.W. (2003). Studying how college affects students. About Campus, 8, 21-28.

Astin, A.W., \& Schroeder, C. (2003). What Matters to Alexander Astin? A Conversation with Higher Education's Senior Scholar. About Campus, 8(5), 11-18. doi: 10.1002/abc.85

Bowen, S. (2005). Engaged learning: Are we all on the same page? Peer Review. Retrieved from:http://findarticles.com/p/articles/mi_ qa4115/is_200501/ai_n13634584/?tag=content;col1.

Carini, R. M., Kuh, G. D \& Klein, S. P. (2006). Student Engagement and Student Learning: Testing the Linkages. Research in Higher Education, 47(1), 1-32

Chickering, A. W., \& Gamson, Z. F. (1987). Seven Principles for Good Practice in Undergraduate Education. AAHE Bulletin, 39(7), 3-7.

Coates, H. (2006). Student Engagement in Campus-based and Online Education. London: Routledge.

Creswell, J. W. (2008). Educational Research (3rd Edition): Planning, Conducting, and Evaluating Quantitative and Qualitative Research. USA: Pearson Prentice Hall.

Dasari, B. (2009). Hong Kong students' approaches to learning: Cross-cultural comparisons. US-China Education Review, 6(12), 46-58.

Engle, J. \& Tinto, V. (2008). Moving Beyond Success. Washington, D.C.: The Pell Institute.

Fauziah Md. Jaafar, Rosna Awang Hashim \& Tengku Faekah Tengku Ariffin. (2012). Malaysian University Student Learning Involvement Scale (MUSLIS): Validation of a Student Engagement Model. Malaysian Journal of Learning and Instruction, 9, 1530.

Griffin, P., Coates, H., McInnis, H. \& James, R. (2003). The Development of an Extended Course Experience Questionnaire. Quality in Higher Education, 9(3), 259-266. doi: 10.1080/135383203200015111.

Hu, S. \& Kuh, G. D. (2002). Being (Dis)engaged in Educationally Purposeful Activities: The Influences of Student and Institutional characteristics. Research in Higher Education, 43(5), 555-575.

Hu, S., Kuh, G. D. \& Gayles, J. G. (2007). Engaging Undergraduate Students in Research Activities: Are Research Universities Doing a Better Job? Innovative Higher Education, 32, 167-177. doi: 10.1007/s10755-007-9043-y.

Hu, S., Kuh, G. D. \& Li, S. (2008). The Effects of Engagement in Inquiry-Oriented Activities on Student Learning and Personal Development. Innovative Higher Education, 33, 71-81. doi: 10.1007/s10755-008-9066-z.

Kuh, G. D. (1998). How are we doing? Tracking the quality of undergraduate experience from the 1960s to the present. Review of higher education, 21(2), 90-120.

Kuh, G. D. (2001). Assessing What Really Matters to Student Learning: Inside the National Survey of Student Engagement. Change, 33(3), 10-17.

Kuh, G.D. (2009). The National Survey of Student Engagement: Conceptual and Empirical Foundations. In P. D. Umbach, New Directions For Institutional Research (pp. 5-20). Wiley InterScience. DOI: 10.1002/ir.

Kuh, G.D., Chen, D., \& Nelson Laird T.F. (2007). Why Teacher-Scholars Matter. Liberal Education, 40-45.

Kuh, G.D. \& Hu, S. (2001). Learning Productivity at Research Universities. The Journal of Higher Education, 72(1), 1-28.

Kuh, G. D., Nelson Laird, T. F \& Umbach, P. D. (2004). Aligning Faculty Activities. Liberal Education. 90(4), 24-31.

Kuh, G. D., Pace, C. R. \& Vesper, N. (1997). The Development of Process Indicators to Estimate Student Gains Associated with Good Practices in Undergraduate Education. Research in Higher Education, 38(4), 435-454.

McInnis, C. (2001). Signs of disengagement? The changing undergraduate experience in Australian universities. Melbourne: Centre for the Study of Higher Education.

Malaysian Qualification Agency (2007). Malaysian Qualifications Framework. Retrieved from MQA website: http://www.mqa.gov.my/en/ utama mqf.cfm.

Ministry of Higher Education. (2007). National Higher Education Strategic Plan: Laying the Foundation Beyond 2020. Retrieved from MOHE website: http://www.mohe.gov.my/transformasi.

National Institute of Education (1984). Involvement in Learning: Realizing the Potential of American Higher Education. Washington, D.C.: U.S. Department of Education.

Pace, C.R. (1982). Achievement and the Quality of Student Effort. Paper presented at National Commission on Excellent in Education (Washington DC).

Pace, C. R. (1984). Measuring the Quality of College Student Experiences. An Account of the Development and Use of the College Student Experience Questionnaire. Los Angeles, CA: University of California.

Pace, C. R. (1990). The Undergraduate: A Report of Their Activities and Progress in College in the 1980s. Los Angeles, CA: University of California.

Pace, C. R. (1998). Recollection and Reflection. In J. C. Smart (ed.), Higher Education: Handbook of Theory and Research (pp. 1-34). London: Kluwer Academic Publisher. 
Pascarella, E. T. \& Terenzini, P. T. (1991). How College Affects Students: Findings and Insights from Twenty Years of Research. San Francisco, CA: Jossey-Bass.

Pascarella, E. T. \& Terenzini, P. T. (2005). How college affects students. San Francisco, CA: Jossey-Bass.

Pascarella, E., Seifert, T. \& Blaich, C. (2010). How Effective are the NSSE Benchmarks in predicting important educational outcomes? Change, 42, 16-22.

Pike, G. R. \& Kuh, G. D. (2005a). A Typology of Student Engagement for American Colleges and Universities. Research in Higher Education, 46(2), 185-209. doi: 10.1007/s 11162-004-1599-0.

Pike, G. R. \& Kuh, G. D. (2005b). First- and Second-Generation College Students: A Comparison of Their Engagement and Intellectual Development. The Journal of Higher Education, 76(3), 276-300.

Shulman, L. S. (2002). Making differences: a table of learning. Change, 34(6), 36-44.

Siti Maziha, M. \& Nik Suryani, N. A. R. (2011). Classroom Participation Patterns: A Case Study of Malaysian Undergraduate Students. International Journal for Educational Studies, 3(2), 145-158.

Tani, M. (2005). Quiet, but only in class: reviewing the in-class participation of Asian students. Retrieved from Higher Education Research and Development Society of Australasia Incorporated (HERDSA) website: http://conference.herdsa.org.au/2005/pdf/ non_refereed/030.pdf.

Thang, S. $\bar{M}$. (2005). Comparing approaches to studying of Malaysian distance learners and on-campus learners: implication to distance education. Turkish Online Journal of Distance Education-TOJDE, 6(2), 70-86.

Thang , S. M. (2009) Investigating autonomy of Malaysian ESL learners: a comparison between public and private universities. 3L; Language, Linguistics and Literature - The Southeast Asian Journal of English Language Studies, 15, 97-124.

Thang, S. M. \& Azarina Alias (2007). Investigating readiness for autonomy: A comparison of Malaysian ESL undergraduates of three public universities. Reflections on English Language Teaching, 6(1), 10-18.

Tinto, V. (1975). Dropout from Higher Education: A Theoretical Synthesis of Current Research. Review of Educational Research, 45(1), 89-125.

Tinto, V. (1987). The Principles of Effective Retention. Paper presented at the Fall Conference of the Maryland College Personnel Association.

Tinto, V. (2000). What Have We Learned About the Impact of Learning Communities on Students? Assessment Update, 12(2), 1-12. 
